\title{
Election outcome signals few policy shifts
}

Washington. Some new faces - but few new ideas - are expected to mould US science policy during the next two months as the White House and the Congress reshuffle their teams after last week's elcctions.

The voting brought no change in the parties in power in either branch of government. President Bill Clinton did not ask his entire cabinet to resign, as other secondterm presidents have done to avoid the embarrassment of sacking individuals. But several resignations have been announced or are expected, starting last week with that of William Perry, the defence secretary.

Perry could well be replaced by John Deutch, a chemist and former provost of the Massachusetts Institute of Technology, who is currently director of the Central Intelligence Agency. Universities believe that Deutch's appointment would boost basic research support from the defence department.

Hazel O'Leary, the energy secretary, is also expected to resign, and Bill Richardson, a Democrat congressman for New Mexico, is being widely tipped as her replacement. But Congress is likely to press strongly for the abolition of the department. There is even speculation that Clinton could agree to a proposal floated by members of the staff of Senator Pete Domenici (Republican, New Mexico) that the department should be turned into an independent agency.

Harold Varmus, director of the National
Institutes of Health (NIH), and Donna Shalala, the health secretary, are both expected to stay on. So are Neal Lane, director of the National Science Foundation (NSF), and Dan Goldin, administrator of the National Aeronautics and Space Administration (NASA).

Jack Gibbons will continue to serve as the president's science adviser, at least for a few
Nature 383, 749; 1996).

Subcommittees of the House of Representatives appropriations committee can expect reshuffling to accommodate the retirement of John Myers (Republican, Indiana) and the ambitions of Joseph McDade (Republican, Pennsylvania), the most senior Republican appropriator, who was denied the chair of the full committee

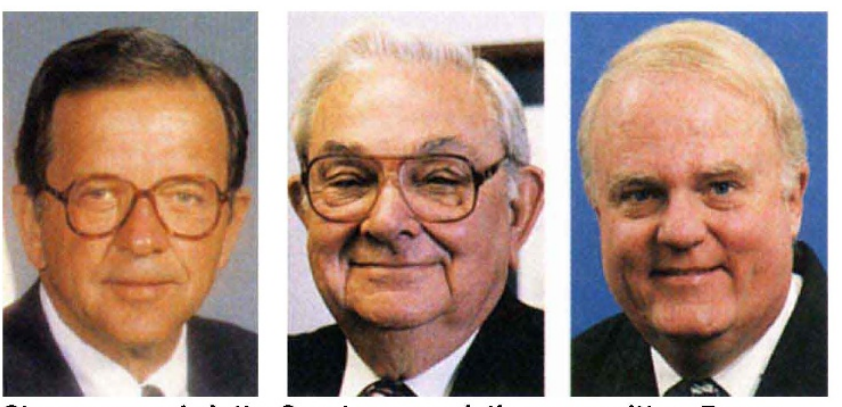

Stevens may chair the Senate appropriations committee, Brown returns and Sensenbrenner may take over science (left to right).

two years ago. But John Edward Porter (Republican, Illinois) is likely to retain his chairmanship of the appropriations subcommittee that funds the NIH.

Meanwhile in the Senate, the NIH's most important ally, Mark Hatfield (Republican, Oregon), is retiring. $\mathrm{He}$ will probably be replaced as chair of the full appropriations committee by Ted Stevens (Republican, Alaska).

Nancy Kassebaum (Republican, Kansas), chair of the Senate Labor

months until a successor is found if he decides to leave.

In Congress, James Sensenbrenner (Republican, Wisconsin) is expected to assume the chairmanship of the Science Committee in the House of Representatives, following the retirement of Robert Walker. Sensenbrenner's main interest is the oversight of NASA, and he has had a combative relationship with Goldin.

George Brown (Democrat, California) will return as the committee's senior minority member, after a tight race whose outcome was not announced for five days (see and Human Resources Committee, which has authorization responsibility for the NIH, has retired. Larry Pressler (Republican, South Dakota), chair of the Senate Commerce, Science and Transportation Committee, which has authorization responsibilities for agencies such as NASA and NSF, was defeated last week.

The departure of these two moderates will mean less benign and more fiscally stringent Senate oversight for the respective agencies, although the names of their successors will not emerge until senators meet later this month.

Colin Macilwain

\section{Affirmative action curb 'will hit minority recruitment'}

San Francisco. Companies in California that rely on state support of minority groups to increase the racial range from which they recruit engineers and scientists have been expressing concern at the approval by voters of a change in the law to prohibit affirmative action in government hiring, contracting and school admissions.

The change in the law - known as 'proposition 209' - was approved last week as part of the California elections by a margin of 54.3 to $\mathbf{4 5 . 7}$ per cent.

Opponents of the proposition have already filed several legal challenges, while civil rights leaders have urged the US Justice Department to help block the law, in particular by invoking civil rights legislation to withhold funds from the University of California.

But supporters of the proposition have also filed suits to ensure compliance. Among their targets is a rule followed by California Community Colleges that race must be a factor in hiring decisions.

Richard C. Atkinson, president of the
University of California, told faculty members and administrative staff last week that the university would comply with the law, but would also continue to emphasize racial diversity. Government officials say they are waiting for a court ruling, although the law took effect immediately.

Gary Fazzino, manager of state government affairs for the computer company Hewlett Packard in Palo Alto, says the company has relied on programmes such as the Math, Engineering, Science Achievement (MESA) programme at the University of California to cultivate promising young scientists and engineers who might join its staff. MESA targets "disadvantaged and historically underrepresented" high-school and college students and provides race-based peer groups, mentors and role models to spur them towards achievement.

"These programmes are essential," says Fazzino. He says such programmes have made a dramatic difference in the number of women and minorities interviewed by the company at leading colleges. Hewlett Packard will maintain its commitment to affirmative action because it makes good business sense, says Fazzino.

Only one company, Pacific Gas \& Electric Co., had taken a public position against proposition 209 before the election. Pete Wilson, the governor of California, publicly rebuked the company for its statements.

Some advocates have suggested that the private sector, including universities such as Stanford and the University of Southern California, should take responsibility for outreach programmes in the absence of government efforts.

Programmes such as MESA serve as a pipeline to deliver qualified students to science and engineering companies, says Mike Beasley, a software manager in Silicon Valley who is chairman of MESA's board. With affirmative action programmes shut down at the universities, there will be more need for such efforts, Beasley says.

Sally Lehrman 